\title{
Between Film, Short Story and Novel Interview with Zbyněk Černík
}

\author{
Karolína Stehlíková
}

Zbyněk Černík (cernikz@volny.cz) is a translator, editor, and writer. From 1977 to 1993, he worked as an editor in the Prague publishing house Odeon. Currently, he works as an editor in Institut uměni - Divadelni ústav (Art Institute - Theatre Institute). Since 1993, he has also been a freelance translator and writer. He has translated works by P. O. Sundman, P. O. Enquist, A. Strindberg, I. Bergman, and many others. He has co-written Slovnik severských spisovateli (Libri, 1998). He is also an author of several children books (Malá medvědi knižka, Medvědi rodinka, Velká medvědi cesta). In 2018, he edited an anthology of four Bergman short stories (Hodina vlků, Kniha Zlín, 2018). Zbyněk Černík has received several awards for his translation. In 1990, he was awarded translator prize of Swedish Academy.

The following interview was carried out as an e-mail conversation in August 2018.

[KS] When did you, as a viewer or a reader, first encounter Bergman?

[ZČ] I guess in the second half of the 1960s as an audience member, when The Seventh Seal (Det sjunde inseglet) was running in the cinemas. I am not sure that I fully understood it then - I was between ten and fifteen years old at the time. In addition there was a minor mistake in the credits at the end of the movie which changed the meaning quite a lot. In Germanic languages the word 'death' has a masculine gender (unlike Czech), so in the literal translation of the 'skeletal woman' unintentionally became the until then unsuccessfully sought-after Master, that is, God. Nevertheless, it made a huge impression on me.

As a reader, I came into contact with Bergman much later, in the 1980s. At that time, I fulfilled my dream and prepared the first Czech anthology of Bergman's film stories as an editor and translator. That was, by the way, very suspenseful because at the time when the book was already being typeset and printed, the maestro somehow misbehaved ideologically in the eyes of the Czechoslovakian 'normalizers', so we awaited trouble and a 'suspension' of the publication. But the party and the government, which used to make decisions about everything, missed it, so the stories were published after all, and even in two editions!

[KS] Which Bergman's movie or text is your favourite and why?

[ZČ] I wouldn't pick just one, there is naturally more: Wild Strawberries (Smultronstället), The Magician (Ansiktet), Through a Glass Darkly (Sasom i en spegel), Winter Light 


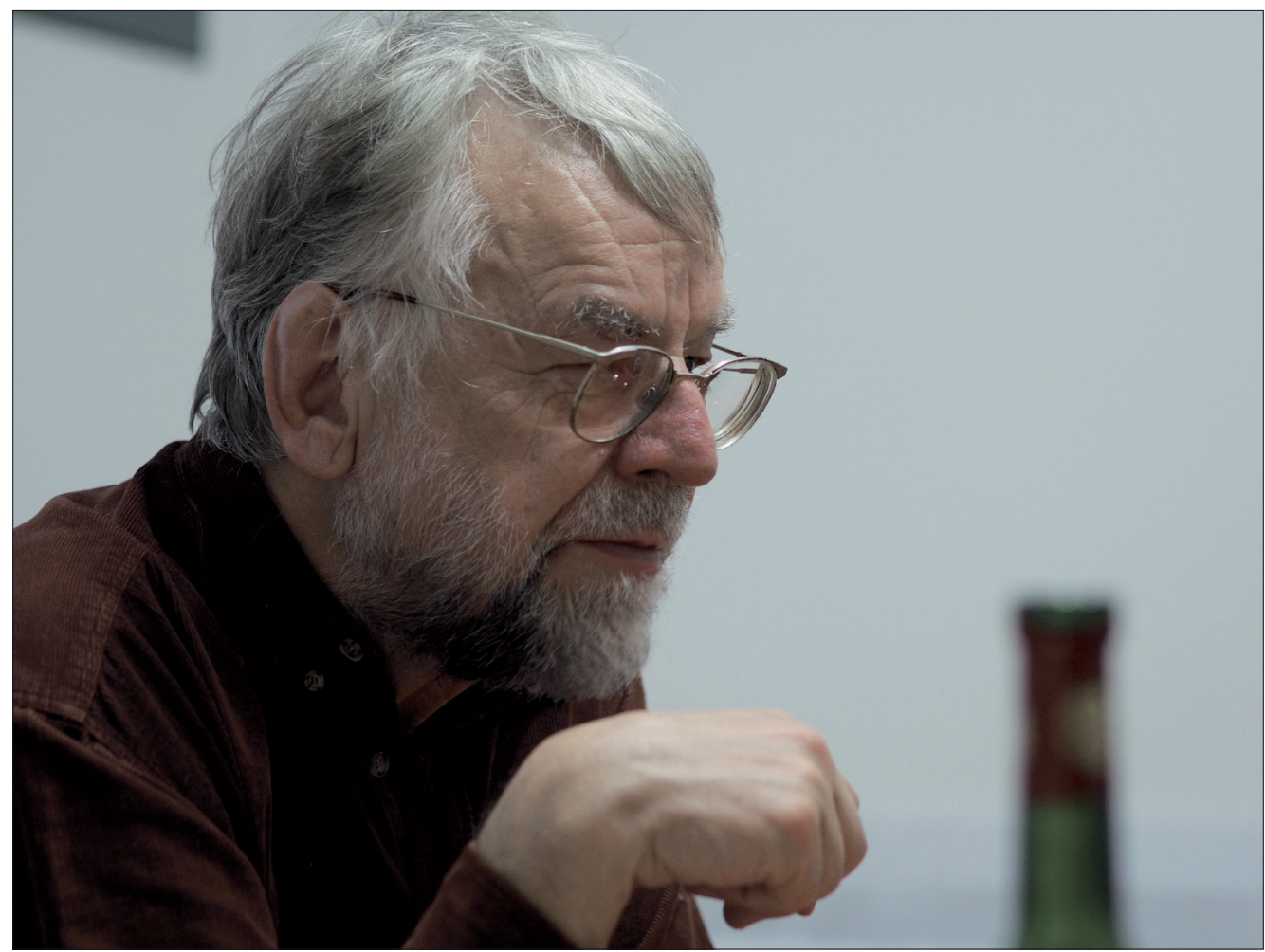

Zbyněk Černík (c) Foto Viktor Vondra.

(Nattvardsgästerna), The Silence (Tystnaden), Persona (Persona), Cries and Whispers (Viskningar och rop), Scenes from a Marriage (Scener ur ett äktenskap), Fanny and Alexander (Fanny och Alexander) and Saraband (Saraband)... Even The Seventh Seal still has something to it, despite the fact that nowadays we perhaps perceive it with a certain indulgence, because the topic of death interpreted in such way seems in these harsh times a bit naive.

[KS] You have created subtitles for a lot of Bergman's movies which have been screened in the Czech Republic. Did you encounter some trickiness while doing so? Is it even difficult to translate Bergman into Czech?

[ZČ] In both his movies and books, Bergman uses fairly specific language, which one needs to get used to. 'Normal' Swedes uncomprehendingly shake their heads to what this man made up. So, the thing is to translate him in a way that the final translation is not flat but at the same time in a way that the reader or viewer does not think that the translator is an ass. I try to do both. Hopefully, I am at least a bit successful.

[KS] In 1982 the publishing house Odeon published the book Film Stories containing scripts of The Seventh Seal, Wild Strawberries, Through a Glass Darkly, Winter Light, The Silence, Scenes from a Marriage and The Serpent's Egg (Ormens ägg). This was the first time any of 
Bergman's text had beenscripts had been published in Czechoslovakia. Who came up with the title 'Film Stories'?

[Zč] Yes, this is the title we were already talking about. I guess it was me who came with the Czech title. Well, not actually came up, rather adopted, Bergman himself did call his texts 'film stories'. Their forms vary significantly, some resemble classical movie scripts, others are almost pure fiction. Their length is also diverse, some, to be more exact (i.e. Fanny and Alexander or The Best Intentions (Den goda viljan)), should be called film novels. In any case, it is a distinctive literary genre, which can be read independently of the movie form of the individual films.

[KS] For almost his whole life, Bergman was an active theatre director. Did you have a chance to see any of his productions?

[ZČ] Yes, I did. I saw a number of productions of the classics (Shakespeare, Ibsen ...) as well as modern dramas (for example Enquist's The Image Makers (Bildmakarna)) in the Royal Dramatic Theater (Kungliga Dramatiska Teatern). It was always perfect, but never cold-heartedly calculated, simply a perfect harmony between the director and the actors.

[KS] I know that you set out to see Bergman at Fårö in 1998, but as many others, who tried the same, you did not get to him. Yet you acquired a very valuable interview with sheep Liv, Hariett, and Bibi during your visit, published in the Svět a divadlo (World and Theatre) magazine $6 / 1998$. What impression did the island itself leave on you?

[ZČ] I made a virtue out of necessity with sheep. Back then, when I had mentioned that I was planning to go to Fårö to the editor in chief of the Svět a divadlo magazine Karel Král, he stated that in that case, I had to get an interview with Bergman. I knew that the chance of being successful is absolutely minuscule, so I took it as a joke. But then as I returned home, Karel Král demanded the interview since he had already advertised it in the previous issue. So, I solved it within the scope. I remembered that by the Dämba village, where I was unsuccessfully looking for Bergman's house, the sheep were grazing, and they were (unlike the people living there, who didn't want to give anything away) constantly baaing 'Bé, béé', as if they wanted to say 'Bé, béé, Béérgman'. ${ }^{1}$ So, I named three of them after the maestro's friends, and put words into their mouths - I mean muzzles - various statements of Bergman, which I had found in Swedish press. I had pretty positive feedback.

But your question was concerned with my impressions of Fårö. It is an island, which is except for the summer season almost entirely desolate and is characterized by fascinating nature. Its features are besides others strange limestone formations, so-called 'rauks', rising above the seashore and the nearby sea. Some of them resemble the everfamous statues on Easter Island. I was impressed in the same way Bergman was when he first arrived there at the end of the 1950 s, i.e., more than thirty years earlier than

1 Translator's note: In Czech, the sound of sheep baaing is 'bé', thus resembling the beginning of Bergman's name. 
me. In his autobiography, The Magic Lantern (Laterna Magica), he writes that it was love at first sight. It was in my case as well, anyway, I really like returning there.

[KS] Last year, you prepared a new anthology of Bergman's texts for the Kniha Zlín publishers. There, we might discover texts Hour of the Woolf (Vargtimmen), Shame (Skammen), The Passion of Anna (En Passion) and From the Life of the Marionettes (Ur marionetternas liv). What was the key to choosing which text to publish?

[ZČ] I chose from those which had not yet been translated but are (at least in my opinion) worth it. The first three texts from the 1960s comprise a loose trilogy, plus Marionettes (from 1980) are not very well known in the Czech Republic, their film versions could have only been seen in film clubs and art cinemas, but one cannot leave them out. Well, and this year another Bergman's volume will be published in Kniha Zlin. The volume will include early texts of Sawdust and Tinsel (Gycklarnas afton), Smiles of a Summer Night (Sommarnattens leende) and The Magician (Ansiktet).

[KS] In 2008, the foundation managing Bergman's archive released the copyrights to stage his texts in theatres. How do you perceive this migration of Bergman from screen to stage?

[ZČ] Bergman's texts have already been staged before. But only outside Sweden - in his homeland the maestro strictly embargoed their performances. For example, when The Vinohrady Theatre wanted to stage Saraband, they were not successful. The Theatre on the Balustrade was eventually successful, with the world premiere in 2008.

In any case, Bergman's film stories are asking to be adapted for the theatre stage. So go on!

[KS] In 2018, Bergman was commemorated in many events all over the world. Did you - either actively or passively - participate?

[ZČ] In connection with the 100th anniversary of Bergman's birth Česká televize (Czech Television) introduced a cycle of Bergman's most famous movies, so once again I did a bit of - or actually a lot of - subtitling. And the Bergman Theatre Week took place in October in Prague (in Kolowrat Palace), during which I did my part - I lectured, to be more precise.

[KS] What do you wish maestro to his 100th birthday?

[ZČ] I cannot wish him anything anymore, given the circumstances, but I definitely selflessly envy him. 